\title{
Elevated Brain Natriuretic Peptide Is Associated with Abnormal Heart Geometry in Children with Chronic Kidney Disease
}

\author{
J. Hedviga ${ }^{\text {a }}$ L.Podrackáa $\quad$ D. Potočeková ${ }^{b}$

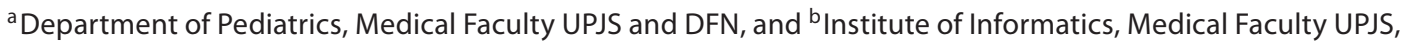 \\ Košice, Slovak Republic
}

\section{Key Words}

Brain natriuretic peptide $\cdot$ Chronic kidney disease $\cdot$ Left ventricular hypertrophy $\cdot$ Cardiac geometry

\begin{abstract}
Aim: It was to establish whether brain natriuretic peptide (BNP) might predict cardiac dysfunction in children with chronic kidney disease (CKD). Methods: The relation between BNP, echocardiography and risk factors (hypertension, anemia, lipids, CRP, hyperparathyroidism) was investigated in 46 children (10 pre-dialysis patients, 14 on dialysis, 11 children with kidney transplants, and 11 healthy controls). Data on BNP were transformed into common logarithms ( $\log _{10}$ BNP, log BNP). Results: log BNP was significantly higher in dialysis patients when compared to controls (2.09 \pm 0.78 vs. $1.43 \pm 0.34 \mathrm{pg} / \mathrm{ml}, \mathrm{p}=0.012$ ) and patients in the predialysis stage ( $2.09 \pm 0.78$ vs. $1.52 \pm 0.42 \mathrm{pg} / \mathrm{ml}, \mathrm{p}=0.039)$. log BNP in transplanted children was not significantly different from healthy children ( $2.09 \pm 0.78$ vs. $1.71 \pm 0.46 \mathrm{pg} / \mathrm{ml}$, $\mathrm{p}=0.19$ ). Abnormal heart geometry (concentric and eccentric hypertrophy, concentric remodeling) was found in 19 patients (54.28\%). A significant correlation was observed between log BNP and ventricular hypertrophy $(r=0.515, p=$ 0.001). Compared to controls higher log BNP was seen in children with eccentric hypertrophy than in children with concentric hypertrophy $(2.178 \pm 0.956$ vs. $1.496 \pm 0.395 \mathrm{pg} / \mathrm{ml}$,
\end{abstract}

$p=0.05$, or $1.982 \pm 0.618$ vs. $1.496 \pm 0.395, p=0.04)$. Conclusions: BNP might predict an abnormal geometry in children with CKD.

Copyright $\odot 2010$ S. Karger AG, Basel

\section{Introduction}

Large-scale, demographic studies from recent decades have shown that cardiovascular diseases are the leading cause of morbidity/mortality in adults with chronic kidney disease (CKD) [1]. In recent years, similar data have also been reported in pediatric patients on chronic dialysis [2]. The most common cardiovascular complication is left ventricular (LV) hypertrophy (LVH), which is documented using echocardiography (ECG) in 75\% of dialyzed patients [3-6].

Because of the unfavorable epidemiological data, researchers have put a great deal of effort into identifying noninvasive and reliable biomarkers which might help to stratify CKD patients according to the presence of cardiovascular risk. Recently, brain natriuretic peptide (BNP) has been identified as a suitable cardiac marker for the assessment of cardiovascular risk in adults. In clinical practice it has already been demonstrated that BNP might be predictive mainly in congestive heart failure. Furthermore, recent studies in adults have revealed that BNP

\section{KARGER \\ Fax +41613061234 E-Mail karger@karger.ch} www.karger.com
(C) 2010 S. Karger AG, Basel

1420-4096/10/0332-0087\$26.00/0

Accessible online at:

www.karger.com/kbr
Prof. MUDr. L. Podracká, CSc.

I. KDD LF UPJŠ a DFN Košice

Tr. SNP č. 1

SK-040 66 Košice (Slovakia)

Tel. +421 55640 4132, E-Mail ludmila.podracka@ upjs.sk 
might reliably detect ventricular dysfunction in uremic patients as well. Thus far, BNP has been used in the pediatric population only rarely, mostly in children with congenital heart defects and/or after heart transplant. It remains to be established whether BNP has the same diagnostic potential in children with CKD. The aim of this study was to find out whether BNP might predict cardiac dysfunction in children with CKD.

\section{Materials and Methods}

The study sample consisted of 46 children: 35 CKD children (19 boys, 16 girls, mean age $16.12 \pm 5.14$ years) and 11 healthy controls ( 5 boys, 6 girls, mean age $14.73 \pm 5.04$ years) comparable by age and sex. The children were divided into the following groups: $10 \mathrm{CKD}$ pre-dialysis children (mean GF $58.09 \mathrm{ml} /$ $\mathrm{min} / 1.73 \mathrm{~m}^{2}$; group 1); 14 children on dialysis (group 2); 11 children with kidney transplants (group 3), and 11 healthy controls (group 4). The associations between the serum level of BNP, ECG and cardiovascular risk factors (hypertension, anemia, lipids, Creactive protein, secondary hyperparathyroidism) were investigated. Approval was given by the local ethics committee, and informed consent was obtained from all the children's parents.

In all of the children studied, blood count, C-reactive protein, electrolytes, renal function, calcium, phosphorus, calcium-phosphorus product, lipid profile, BNP, proteinuria and ECG were examined. For BNP, $2.5 \mathrm{ml}$ of blood were deposited in an EDTA tube. The sample was immediately centrifuged at $6,000 \mathrm{rpm}$ and a temperature of $4^{\circ} \mathrm{C}$ for $20 \mathrm{~min}$; the plasma obtained was then frozen at $-80^{\circ} \mathrm{C}$ until BNP examination. BNP (Abbott) was performed by a microparticle enzyme immunoassay. ECG was performed on a Siemens Acuson CV70 using a 3.5-MHz sectoral probe according to the American Society of Echocardiography Guidelines. Interventricular diastolic diameter (IVSd), left ventricle posterior wall diastolic diameter (LVPWd) and systolic and diastolic LV diameters (LVDs, LVDd) were measured in each child. Left ventricle mass was indexed to height and expressed in $\mathrm{g} / \mathrm{m}^{2.7}$ (LVMI). Relative wall thickness (RWT) was determined as a ratio of the sum of the interventricular diastolic diameter and the LV posterior wall divided by LV diastolic diameter (IVSD+LVPWd/LVDd). Concentric remodeling was defined as an RWT of $>0.45$, which is in the 95th percentile in the healthy control group. LVH was defined as an LMVI of $>37.6 \mathrm{~g} / \mathrm{m}^{2.7}$ (95th percentile in the healthy control group). Concentric LVH was defined as an RWT of $>0.45$ and LVM/height ${ }^{2.7}$ of $>37.6 \mathrm{~g} / \mathrm{m}^{2.7}$, while eccentric LVH was defined as an RWT of $<0.45$ and LVM/ height ${ }^{2.7}$ of $>37.6 \mathrm{~g} / \mathrm{m}^{2.7}$.

Hypertension is defined as average systolic and/or diastolic blood pressure that is $\geq 95$ th percentile for gender, age, and height on 3 or more separate occasions [7].

\section{Statistics}

The obtained results were processed using Statistica $\mathrm{Cz} 6.0$ by StatSoft, Arcus Quickstat Biomedical v.1.1 and Microsoft Excel 2003. We used the Student $t$ test for independent samples for confirmation of the hypothesis equality of middle values in two groups. ANOVA with subsequent LSD test was used in several groups. In conditions of failure of normality data we used the Mann-Whitney U test or the Kruskal-Wallis ANOVA. Pearson correlation analysis was used to evaluate the ratio between the variables. The differences in occurrence of the given characteristics were tested in selected samples using the $\chi^{2}$ test, or Fisher's exact test. To exclude any influence of the distribution of BNP plasma level values, data were transformed into BNP common logarithms $\left(\log _{10} \mathrm{BNP}, \log \mathrm{BNP}\right)$. The relation between secondary hyperparathyroidism, anemia and heart damage was assessed separately. Values of $\mathrm{p} \leq 0.05$ were considered statistically significant.

\section{Results}

\section{Clinical Characteristics}

The most common underlying disease in the studied cohort was renal hypo-/dysplasia, which occurred in $41 \%$ of all patients, while $34 \%$ of patients suffered from congenital or hereditary nephropathies, and the remaining $25 \%$ have had glomerulonephritis. Just over half (54\%) of all patients were being treated for hypertension. The distribution of hypertension among the groups studied was as follows: $41 \%$ of the pre-dialyzed patients (group 1) were hypertensive, and $54 \%$ of the dialyzed patients (group 2) and $63 \%$ of the transplanted patients (group 3) were designated as hypertensive. $32 \%$ of the hypertensive patients were using monotherapy with an angiotensin-converting enzyme blocker (ACEi); $16 \%$ received a combination of ACEi and angiotensin I receptor blocker (AT1), and 52\% patients received some other form of antihypertensive treatment. The clinical, hematological and biochemical parameters of all patients studied are shown in table 1 and figures 1 and 2 . The mean values of the investigated parameters have been compared between all of the studied groups.

\section{Echocardiography}

Table 2 summarizes the ECHO findings.

Abnormal heart geometry was found in 19 subjects (3 pre-dialyzed, 10 dialyzed and 6 transplanted children) accounting for $54.28 \%$ of the whole cohort of 35 patients studied. Among these, 10 patients (28.57\%) were found to have concentric left ventricle hypertrophy, 6 patients (17.14\%) had eccentric left ventricle hypertrophy, and 3 patients suffered from concentric remodeling of the left ventricle. LVMI and RWT were significantly higher in the dialyzed patients $(\mathrm{p}<0.001)$ and the transplanted patients $(\mathrm{p}<0.015)$ compared to the healthy group. LVH occurred significantly more often in both dialyzed and treated children when compared to the pre-dialysis group as well as the healthy controls. The distribution of LMVI, an indicator of LVH and RWT, is shown in figure 3. 


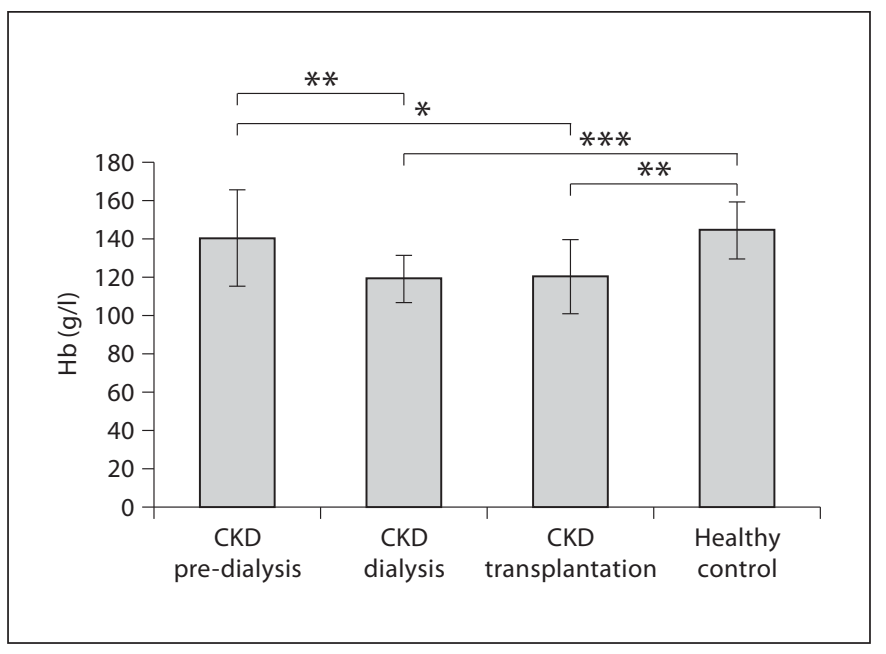

Fig. 1. Average hemoglobin $(\mathrm{Hb})$ in 46 children. ANOVA $\mathrm{p}=$ $0.017 ;^{*} \mathrm{p}<0.05 ;^{* *} \mathrm{p}<0.01$; $^{* *} \mathrm{p}<0.001$.

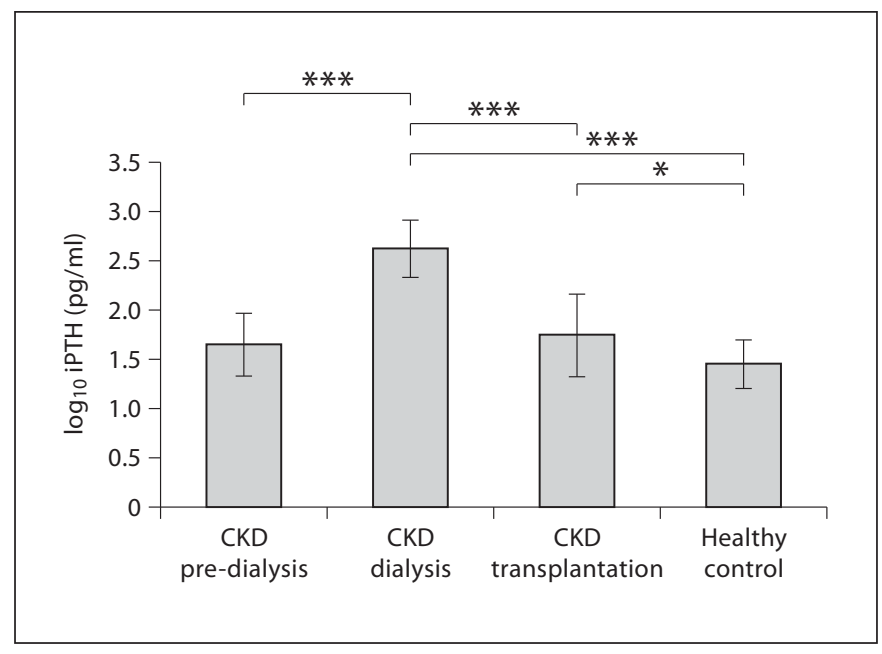

Fig. 2. Average parathormone $\left(\log _{10} \mathrm{iPTH}\right)$ in 46 children. ANOVA $\mathrm{p}<0.0001 ;{ }^{*} \mathrm{p}<0.05 ;{ }^{* *} \mathrm{p}<0.001$.

Table 1. Laboratory data of the patients with chronic kidney disease (CKD) and the control groups

\begin{tabular}{|c|c|c|c|c|c|}
\hline Parameter & $\begin{array}{l}\text { Group } 1 \\
\text { CKD, pre-dialysis }\end{array}$ & $\begin{array}{l}\text { Group } 2 \\
\text { CKD, dialysis }\end{array}$ & $\begin{array}{l}\text { Group } 3 \\
\text { CKD, transplantation }\end{array}$ & $\begin{array}{l}\text { Group } 4 \\
\text { Healthy controls }\end{array}$ & $\mathrm{p}$ value \\
\hline $\mathrm{Hb}, \mathrm{g} / \mathrm{l}$ & $\begin{array}{l}141.21 \pm 25.23 \\
\text { group } 2^{* *}, \text { group } 3^{*}\end{array}$ & $\begin{array}{l}119.41 \pm 12.07 \\
\text { group } 1^{* *}, \text { group } 4^{* * *}\end{array}$ & $\begin{array}{l}120.63 \pm 19.07 \\
\text { group } 1^{*}, \text { group } 4^{* *}\end{array}$ & $\begin{array}{l}145 \pm 15 \\
\text { group } 2^{* * *}, \text { group } 3^{* *}\end{array}$ & 0.017 \\
\hline CRP, mg/l & $2.95 \pm 3.52$ & $10.52 \pm 11.18$ & $3.24 \pm 3.59$ & $<5.0$ & n.s. \\
\hline Creatinine, $\mu \mathrm{mol} / \mathrm{l}$ & $\begin{array}{l}164.10 \pm 63.56 \\
\text { groups } 2,4^{* * *}\end{array}$ & $\begin{array}{l}548.79 \pm 199.83 \\
\text { groups } 1,3,4^{* * *}\end{array}$ & $\begin{array}{l}129.18 \pm 20.77 \\
\text { groups } 1,4^{* * *}\end{array}$ & $\begin{array}{l}59.55 \pm 14.89 \\
\text { groups } 1-3^{* * *}\end{array}$ & $<0.001^{\mathrm{a}}$ \\
\hline $\mathrm{GF}, \mathrm{ml} / \mathrm{min} / 1.73 \mathrm{~m}^{2}$ & $\begin{array}{l}58.09 \pm 27.29 \\
\text { groups } 2,4^{* * *}\end{array}$ & $\begin{array}{l}14.20 \pm 6.11 \\
\text { groups } 1,3,4^{* * *}\end{array}$ & $\begin{array}{l}58.55 \pm 15.01 \\
\text { groups } 2,4^{* * *}\end{array}$ & $\begin{array}{l}98 \pm 6 \\
\text { groups } 1-3^{* * *}\end{array}$ & $<0.001^{\mathrm{a}}$ \\
\hline Cholesterol, mmol/l & $4.75 \pm 1.15$ & $\begin{array}{l}5.23 \pm 1.22 \\
\text { group } 4^{*}\end{array}$ & $4.95 \pm 1.43$ & $\begin{array}{l}4.35 \pm 0.85 \\
\text { group } 2^{*}\end{array}$ & $0.01^{\mathrm{a}}$ \\
\hline Homocysteine, $\mu \mathrm{mol} / \mathrm{l}$ & $9.76 \pm 1.72$ & $15.18 \pm 9.14$ & $13.38 \pm 3.92$ & $9.7 \pm 5.7$ & n.s. \\
\hline $\mathrm{Ca}, \mathrm{mmol} / \mathrm{l}$ & $2.45 \pm 0.11$ & $2.36 \pm 0.23$ & $2.37 \pm 0.14$ & $2.52 \pm 0.11$ & 0.07 \\
\hline $\mathrm{P}, \mathrm{mmol} / \mathrm{l}$ & $\begin{array}{l}1.10 \pm 0.24 \\
\text { group } 2^{* * *}\end{array}$ & $\begin{array}{l}1.76 \pm 0.41 \\
\text { groups } 1,3,4^{* * *}\end{array}$ & $\begin{array}{l}1.13 \pm 0.23 \\
\text { group } 2^{* * *}\end{array}$ & $\begin{array}{l}1.23 \pm 0.26 \\
\text { group } 2^{* * *}\end{array}$ & $<0.0001$ \\
\hline $\mathrm{Ca} \times \mathrm{P}, \mathrm{mmol}^{2} / \mathrm{l}^{2}$ & $\begin{array}{l}2.71 \pm 0.61 \\
\text { group } 2^{* *}\end{array}$ & $\begin{array}{l}4.21 \pm 1.15 \\
\text { groups } 1,3^{* *}, \text { group } 4^{*}\end{array}$ & $\begin{array}{l}2.71 \pm 0.62 \\
\text { group } 2^{* *}\end{array}$ & $\begin{array}{l}3.10 \pm 0.71 \\
\text { group } 2^{*}\end{array}$ & $0.002^{\mathrm{a}}$ \\
\hline iPTH, pg/ml & $56.50 \pm 45.01$ & $496.71 \pm 306.45$ & $96.10 \pm 151.66$ & $32.32 \pm 20.49$ & \\
\hline $\log _{10}$ iPTH, pg/ml & $\begin{array}{l}1.66 \pm 0.31 \\
\text { group } 2^{* * *}\end{array}$ & $\begin{array}{l}2.61 \pm 0.29 \\
\text { groups } 1,3,4^{* * *}\end{array}$ & $\begin{array}{l}1.74 \pm 0.42 \\
\text { group } 2^{* * *}, \text { group } 4^{*}\end{array}$ & $\begin{array}{l}1.44 \pm 0.25 \\
\text { group } 2^{* * *}, \text { group } 3^{*}\end{array}$ & $<0.0001$ \\
\hline $\mathrm{BNP}, \mathrm{pg} / \mathrm{ml}$ & $52.33 \pm 58.14$ & $498.77 \pm 800.04$ & $89.32 \pm 108.82$ & $35.25 \pm 25.20$ & \\
\hline $\log _{10} B N P, p g / m l$ & $\begin{array}{l}1.53 \pm 0.42 \\
\text { group } 2^{*}\end{array}$ & $\begin{array}{l}2.09 \pm 0.78 \\
\text { groups } 1,4^{*}\end{array}$ & $1.71 \pm 0.46$ & $\begin{array}{l}1.44 \pm 0.34 \\
\text { group } 2^{*}\end{array}$ & 0.024 \\
\hline
\end{tabular}

${ }^{* * *} \mathrm{p}<0.001 ;{ }^{* *} \mathrm{p}<0.01 ;{ }^{*} \mathrm{p}<0.05 .{ }^{a}$ Kruskal-Wallis ANOVA. 
Table 2. ECHO findings of the 46 study patients

\begin{tabular}{|c|c|c|c|c|c|c|}
\hline $\mathrm{ECHO}$ & $\begin{array}{l}\text { All patients } \\
(\mathrm{n}=35)\end{array}$ & $\begin{array}{l}\text { Group } 1 \\
\text { CKD, pre-dialysis } \\
(\mathrm{n}=10)\end{array}$ & $\begin{array}{l}\text { Group } 2 \\
\text { CKD, dialysis } \\
(\mathrm{n}=14)\end{array}$ & $\begin{array}{l}\text { Group } 3 \\
\text { CKD, transplan- } \\
\text { tation }(\mathrm{n}=11)\end{array}$ & $\begin{array}{l}\text { Group } 4 \\
\text { Healthy control } \\
(\mathrm{n}=11)\end{array}$ & $\begin{array}{l}\mathrm{p} \\
\text { value }\end{array}$ \\
\hline LV mass, $\mathrm{g} / \mathrm{m}^{2.7}$ & $40.69 \pm 19.12$ & $\begin{array}{l}30.01 \pm 13.33 \\
\text { group } 2^{* *}\end{array}$ & $\begin{array}{l}49.17 \pm 19.61 \\
\text { group } 1^{* *}, \text { group } 4^{* * *}\end{array}$ & $\begin{array}{l}39.63 \pm 19.16 \\
\text { group } 4^{*}\end{array}$ & $\begin{array}{l}22.45 \pm 6.65 \\
\text { group } 2^{* *}, \text { group } 3^{*}\end{array}$ & $0.005^{\mathrm{a}}$ \\
\hline RWT & $0.42 \pm 0.18$ & $0.39 \pm 0.08$ & $0.45 \pm 0.23$ & $0.40 \pm 0.19$ & $0.32 \pm 0.08$ & $0.09^{a}$ \\
\hline Normal geometry, $\mathrm{n}$ & $16(45.71 \%)$ & $\begin{array}{l}7(70.0 \%) \\
\text { group } 4, p<0.09\end{array}$ & $\begin{array}{l}4(28.57 \%) \\
\text { group } 4^{* * *}\end{array}$ & $\begin{array}{l}5(45.45 \%) \\
\text { group } 4^{* *}\end{array}$ & $11(100 \%)$ & $<0.001$ \\
\hline \multicolumn{7}{|l|}{ Abnormal geometry } \\
\hline Eccentric LVH, n & $6(17.14 \%)$ & $\begin{array}{l}0 \\
\text { n.s. }\end{array}$ & $\begin{array}{l}4(28.57 \%) \\
\text { n.s. }\end{array}$ & $\begin{array}{l}2(18.18 \%) \\
\text { n.s. }\end{array}$ & 0 & n.s. \\
\hline Concentric LVH, n & $10(28.57 \%)$ & $\begin{array}{l}2(20.0 \%) \\
\text { n.s. }\end{array}$ & $\begin{array}{l}5(35.71 \%) \\
\text { group } 4^{*}\end{array}$ & $\begin{array}{l}3(27.27 \%) \\
\text { n.s. }\end{array}$ & 0 & 0.045 \\
\hline Remodeling, $\mathrm{n}$ & $3(8.57 \%)$ & $\begin{array}{l}1(10.0 \%) \\
\text { n.s. }\end{array}$ & $\begin{array}{l}1(7.14 \%) \\
\text { n.s. }\end{array}$ & $\begin{array}{l}1(9.09 \%) \\
\text { n.s. }\end{array}$ & 0 & n.s. \\
\hline
\end{tabular}

$\mathrm{LV}=$ Left ventricle; $\mathrm{LVH}=$ left ventricle hypertrophy; RWT = relative wall thickness.

${ }^{* * *} \mathrm{p}<0.001 ;{ }^{* *} \mathrm{p}<0.01 ;{ }^{*} \mathrm{p}<0.05$. ${ }^{\mathrm{a}}$ Mann-Whitney U test.

\section{BNP Measurements}

A significant difference in log BNP was revealed between the individual groups studied by analytical dispersion $(\mathrm{p}=0.024)$. The values of $\log$ BNP in dialyzed patients $(2.09 \pm 0.78 \mathrm{pg} / \mathrm{ml})$ were significantly higher compared to healthy controls $(1.43 \pm 0.34 \mathrm{pg} / \mathrm{ml}, \mathrm{p}=0.012)$ and to pre-dialysis patients $(1.52 \pm 0.42 \mathrm{pg} / \mathrm{ml}, \mathrm{p}=0.039)$ as well as to treated patients $(1.71 \pm 0.46 \mathrm{pg} / \mathrm{ml}, \mathrm{p}=0.19)$.

\section{BNP and ECG}

Significantly higher mean values of log BNP were observed in patients with LVH compared to patients without LVH (2.01 \pm 0.71 vs. $1.54 \pm 0.43, \mathrm{p}=0.038$, MannWhitney test). Moreover, a statistically significant association between LVMI and log BNP was confirmed by correlative analysis $(\mathrm{r}=0.515, \mathrm{p}<0.001, \mathrm{y}=1.126+$ $0.016^{*} \mathrm{x}$; fig. 4). In addition, when patients were divided according to the type of heart geometry, it was revealed that $\log$ BNP was significantly higher in children with eccentric LVH (2.178 \pm 0.956 vs. $1.496 \pm 0.395, \mathrm{p}=0.05)$ than with concentric LVH $(1.982 \pm 0.618$ vs. $1.496 \pm$ $0.395, \mathrm{p}=0.04)$.

BNP and Secondary Hyperparathyroidism

In patients with secondary hyperparathyroidism log BNP was significantly higher than in those with low PTH $(1.95 \pm 0.71$ vs. $1.53 \pm 0.39, \mathrm{p}=0.03$, Mann-Whitney test). Also, a highly significant correlation was observed between LVMI and $\log$ BNP $(r=0.716, p=0.0003)$ but not in those children with low PTH. The higher the iPTH levels, the higher the BNP values and LVMI $\left(\log _{10} \mathrm{iPTH}\right.$ vs. $\log _{10}$ BNP: $r=0.374, p=0.010 ; y=0.979+0.388^{*} x$ ). Moreover, BNP correlated significantly with the $\mathrm{Ca} \times \mathrm{P}$ product $(\mathrm{r}=0.4413, \mathrm{p}=0.0021)$ as well as with RWT $(\mathrm{r}=$ $0.3583, \mathrm{p}=0.0145)$.

BNP and Anemia

A significantly higher log BNP was observed in patients with anemia when compared to patients without anemia (2.074 \pm 0.755 vs. $1.561 \pm 0.353, p=0.027$, MannWhitney test). Moreover, subjects with high BNP levels $(>100 \mathrm{pg} / \mathrm{ml}$ ) showed a high predictive value for the incidence of anemia (OR $=7.111 ; 95 \%$ CI 1.23, 40.98).

\section{Discussion}

Children with CKD bear a high burden of cardiovascular damage and have been recognized as one of the highest cardiovascular risk groups among the entire pediatric population. The reasons for cardiovascular risk in children with renal diseases are many. In addition to traditional cardiovascular risks, there are so-called uremiarelated risks, such as anemia, $\mathrm{LVH}$, bone-vessel disease 


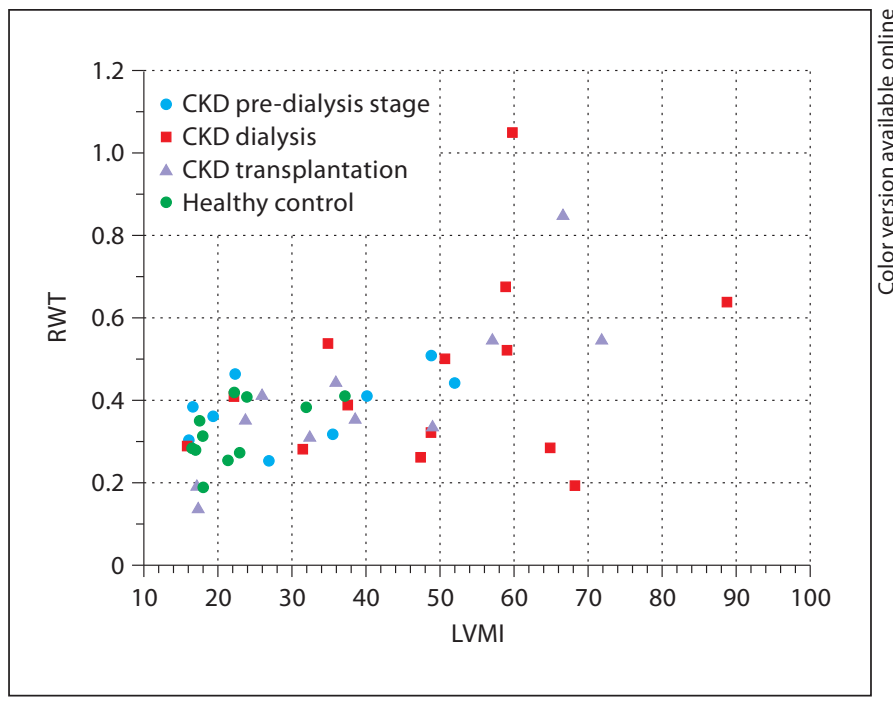

Fig. 3. Left ventricle mass index (LVMI) in patients with pre-dialysis stage, dialysis and transplantation. RWT = Relative wall thickness.

(hyperparathyroidism, hypocalcemia, hyperphosphatemia, loss of vitamin D), hyperhomocysteinemia, inflammation, and others, in children with CKD. Early markers of cardiomyopathy, such as LVH and LV dysfunction, are frequently found in this patient population. There are several ways to define LVH in children using an ECG. Pediatric cardiologists mostly recommend using the calculation of the left ventricle mass-to-height index $[8,9]$. Recent studies have confirmed that 'this indexation' is useful also for the cardiovascular prognosis of adult patients [10]. In our study, similar to others $[8,9,11]$, we defined LVMI with regard to the actual height of the child examined, so that a relevant comparison of our results can be made with the data published in the literature.

In the present study, abnormal heart geometry was found in more than half of the patients studied including pre-dialysis, dialyzed and transplanted children. Concentric LVH was more frequent than eccentric LVH. Our results are in agreement with the conclusions of a major multicentric European study which revealed a surprisingly frequent occurrence of $\mathrm{LVH}$ in children with CKD [12], detecting it in 35\% of 156 children suffering from $\mathrm{LVH}$ in the pre-dialysis stage. However, the incidence of LVH in our study was higher, and can be explained by the fact that one third of our patients were already on chronic dialysis. This explanation is also supported by several clinical observations in adult patients, showing that LVMI is growing inversely with a progressive decline in

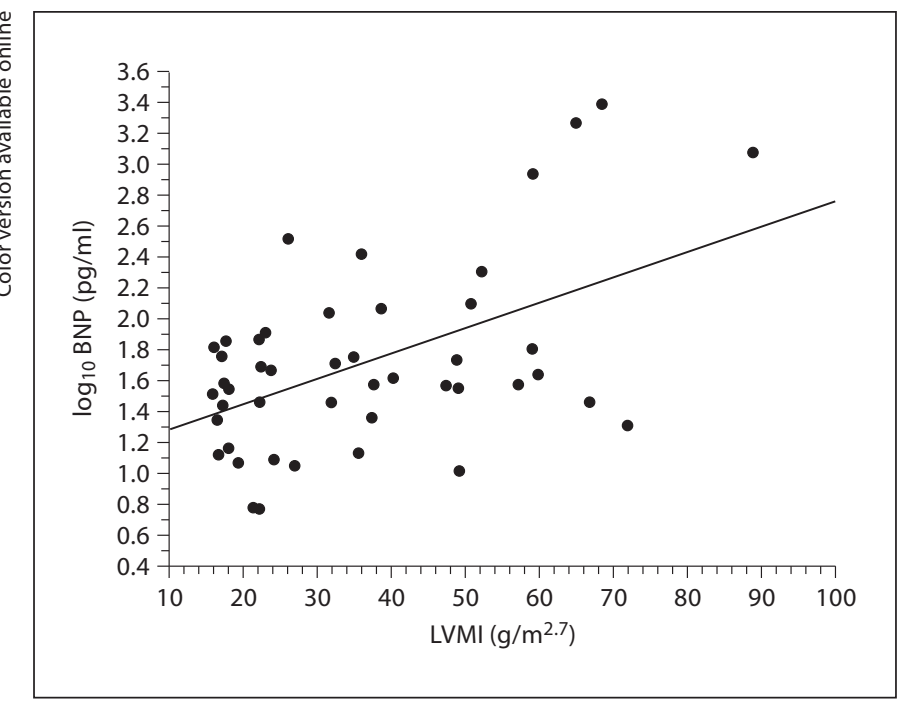

Fig. 4. The correlation between brain natriuretic peptide (BNP) and left ventricular mass index (LVMI). $\mathrm{r}=0.5146, \mathrm{p}=0.0003$; $y=8.507+16.168^{*} x$.

renal function and can reach twice the normal value in dialyzed patients.

On the other hand, abnormal heart geometry was already present in a third of our pre-dialysis children. Two other studies devoted to the relation between heart geometry and the early stage of renal insufficiency in children found that concentric LVH is more frequent than eccentric LVH (the latter dominates in dialyzed children) [13]. Together with other facts, this might suggest that left ventricle remodeling already occurs in the early stages of CKD. In the advanced or terminal stages of CKD, the main factor contributing to concentric or eccentric remodeling is hypertension and volume overload. The left ventricle adapts to the increasing afterload by concentric remodeling, and the increased preload activates eccentric remodeling [14]. The impact of volume overload can be shown by the higher log BNP values in children with eccentric LVH than in children with concentric LVH. Another surprising conclusion of the multicentric pediatric study is that the distribution of the left ventricle geometry does not correlate with the presence of arterial hypertension. Interestingly, in our study hypertension also did not correlate with ECG findings or with antihypertensive drugs in our patients. Further research is needed to find out whether arterial hypertension plays a lesser role in this process than was previously thought. One of the speculative explanations is the cardioprotective influence of ACEi or the combined treatment with ACEi and AT1. 
It cannot be excluded that early antihypertensive treatment can mask an underlying association of blood pressure and concentric LV geometry by preventing or reversing concentric $\mathrm{LVH}$.

ECG examination is indicated in the selected group of patients. For this reason noninvasive tests are being sought to serve as diagnostic markers of cardiac dysfunction. Recently, the monitoring of plasma BNP and n-terminal BNP (nT-BNP) has been found to be useful for predicting cardiovascular morbidity and mortality. The rise in LV mass and pressure overload independently stimulates the synthesis of BNP, and thus the plasmatic values of BNP and nT-BNP might 'truly' reflect cardiac mass and function [8-10]. In addition to myocardial dysfunction, renal functions may also influence BNP synthesis $[15,16]$. This explains the difficulties with interpretation of higher BNP values in patients with CKD.

Cox's regression multivariate analysis was used to discover whether this is the result of decreased glomerular filtration or the direct influence of myocardial injury. The above statistical approach is able to 'separate' a contribution of low renal clearance from the whole plasmatic value of BNP. Using this statistical model, it was confirmed that higher BNP values are independent predictors of heart pathology also in patients with CKD. Zoccali et al. [17], in a study of 246 dialyzed patients without heart failure, were the first to describe that cardiac natriuretic peptides (ANP and BNP) are independent predictors of ejection fraction in CKD subjects. In all of the measured parameters, BNP reflected LVH more reliably than ANP and thus independently predicted patient mortality [18]. Cataliotti et al. [15] also pointed out that patients who died of cardiovascular events had significantly higher BNP values than those who survived such events. Our observations also support the conclusion that BNP has a good predictive value. We have demonstrated that patients with LVH have significantly higher mean BNP values than patients without LVH. In addition, a positive significant correlation between LVH and $\log$ BNP was also found.

The causes of cardiovascular disabilities in renal patients are multifactorial. Anemia and bone disease have received a great deal of attention in recent years. Renal anemia is a traditional and very common long-term consequence of CKD. In uremic patients, the supplementation of oxygen into the myocardium remains at a decreased level despite its increasing demand. The increased preload and decreased compensatory afterload maintain tissue oxygenation, but an eventual consequence of this protective pathophysiological mechanism becomes myo- cardial remodeling. The importance of anemia is underlined by longitudinal studies in adults showing relevant evidence that changes in hemoglobin go 'hand in hand' with changes in LV mass [10]. Also, in our study renal anemia occurred significantly more often in patients with high BNP values, with a high predictive value.

Recently, it has been proven that the onset of vascular calcifications is induced by hyperphosphatemia and secondary hyperparathyroidism [19]. In agreement with the above findings, our results also indicate a strong association between cardiovascular risk and bone-vascular disease, since our children with secondary hyperparathyroidism showed significantly higher BNP values. Furthermore, BNP was significantly correlated with the $\mathrm{Ca}$ $\times$ P product, RWT and LVMI. To the best of our knowledge, we are the first to demonstrate that BNP might correlate with secondary hyperparathyroidism in children with CKD. Thus, our results support previous considerations that abnormalities in bone metabolism are directly linked to cardiovascular impairment in the pediatric renal population.

\section{Conclusion}

Our cross-sectional single-center study supports previously published data showing a high incidence of cardiac dysfunction in children with CKD. We have found higher log BNP in CKD children, a high proportion of abnormal heart geometry and a correlation between BNP, LVMI, parathyroid hormone level and anemia. Our preliminary results thus indicate that BNP might be a suitable marker for cardiovascular stratification in the pediatric CKD population. However, more prospective studies on a larger group of pediatric patients are required.

\section{Acknowledgments}

This work was supported by the project 'Centre for Excellent Research of Atherosclerosis and Its Complications - Myocardial Infarction and Stroke', the Operational Program of Research and Development financed by the European Fund for Regional Development, and VEGA grant No. 1/0805/08. 


\section{References}

-1 Foley RN, Parfrey PS, Sarnak MJ: Clinical epidemiology of cardiovascular disease in chronic renal disease. Am J Kidney Dis 1998; 32(suppl 3):S112-S119.

$\checkmark 2$ Chavers BM, Li S, Collins AJ, Herzog CA: Cardiovascular disease in pediatric chronic dialysis patients. Kidney Int 2002;62:648653.

3 Parfrey PS, Foley RN: The clinical epidemiology of cardiac disease in chronic renal failure. J Am Soc Nephrol 1999;10:1606-1615.

$\checkmark 4$ Mitsnefes MM, Daniels SR, Schwartz SM, Meyer RA, Khoury P, Strife CF: Severe left ventricular hypertrophy in pediatric dialysis: prevalence and predictors. Pediatr Nephrol 2000;14:898-902.

$\checkmark 5$ Longenecker JC, Coresh J, Power NR, Levey AS, Fink NE, Martin A, Klag MJ: Traditional cardiovascular risk factors in dialysis patients compared with general population: The CHOICE study. J Am Soc Nephrol 2002; 13:1918-1927.

6 Gruppen, MP, Groothoff, JW, Prins, M, van der Wouw P, Offringa M, Bos WJ, Davin JC, Heymans HS: Cardiac disease in young adults patients with end-stage renal disease since childhood: a Dutch cohort study. Kidney Int 2003;63:1058-1065.

7 National High Blood Pressure Education Program Working Group on High Blood Pressure in Children and Adolescents: The fourth report on the diagnosis, evaluation, and treatment of high blood pressure in children and adolescents. Pediatrics 2004; 114(suppl):555-576.
-8 Daniels SR, Kimball TR, Morrison JA, Khoury P, Meyer RA: Indexing left ventricular mass to account for differences in body size in children and adolescents without cardiovascular disease. Am J Cardiol 1995;76: 699-701.

$\checkmark 9$ Urbina EM, Gidding SS, Bao W, Pickoff AS, Berdusis K, Berenson GS: Effect of body size, ponderosity, and blood pressure on left ventricular growth in children and young adults in the Bogalusa Heart Study. Circulation 1995;91:2400-2406.

10 de Simone G, Kizer J, Chinali M, Roman MJ, Bella JN, Best LG, Lee ET, Devereux RB: Normalization for body size and population-attributable risk of left ventricular hypertrophy: the Strong Heart Study. Am J Hypertens 2005;18:191-196.

11 Levy D, Garrison RJ, Savage DD, Kannel WB, Castelli WP: Prognostic implications of echocardiographically determined left ventricular mass in Framingham Heart Study. N Engl J Med 1990;322:1561-1566.

12 Matteucci MC, Wühl E, Picca S, Mastrostefano A, Rinelli G, Romano C, Rizzoni G, Mehls O, de Simone G, Schaefer F, ESCAPE Trial Group: Left ventricular geometry in children with mild to moderate chronic renal insufficiency. J Am Soc Nephrol 2006; 17: 218-226.

13 Mitsnefes MM, Kimball TR, Border WL, Witt SA, Glascock BJ, Khoury PR, Daniels SR: Impaired left ventricular diastolic function in children with chronic renal failure. Kidney Int 2004;65:1461-1466.

14 Grossman W, Jones D, McLaurin LP: Wall stress and patterns of hypertrophy in the human left ventricle. J Clin Invest 1975;56: 56-64.
15 Cataliotti A, Malatino L, Jougasaki M, Zocalli C, Castellino P, Glacone G, Bellanuova I, Tripepi R, Seminara G, Parlongo S, Stancanelli B, Bonanno G, Fatuzzo P, Rapisarda F, Belluardo P, Signorelli SS, Heublein DM, Lainchburry JG, Leskinen HK, Bailey KR, Redfield MM, Burnett JC Jr: Circulating natriuretic peptide concentrations in patients with end-stage renal disease: role of brain natriuretic peptide as a biomarker for ventricular remodeling. Mayo Clin Proc 2001;76: 1111-1119.

16 Clerico A, Capriolo R, Del Ry S, Gianessi D: Clinical relevance of cardiac natriuretic peptides measured by means of competitive and non-competitive immunoassay methods in patients with renal failure on chronic hemodialysis. J Endocrinol Invest 2001;24:24-30.

17 Zoccali C, Mallamaci F, Benedetto FA, Tripepi G, Parlongo S, Cataliotti A, Cutrupi S, Giacone G, Bellanuova I, Cottini E, Malatino LS; Creed Investigators: Cardiac natriuretic peptides are related to left ventricular mass and function and predict mortality in dialysis patients. J Am Soc Nephrol 2001;12:15081515.

18 Sillberg JS, Barre PE, Prichard SS, Sniderman AD: Impact of left ventricular hypertrophy on survival in end-stage renal disease. Kidney Int 1989;36:286-290.

19 Blacher J, Guerin AP, Pannier B, Marchais SJ, London GM: Arterial calcifications, arterial stiffness, and cardiovascular risk in endstage renal disease. Hypertension 2001;38: 938-942. 